\title{
Sistem Informasi Pembayaran Sumbangan Partisipasi Pendidikan Terintegrasi SMS Gateway
}

\author{
M. Rifqi Firdaus ${ }^{1}$, M. Ifan Rifani Ihsan², Arief Rama Sena ${ }^{3}$, Rizka Dahlia ${ }^{4}$ \\ ${ }^{1}$ Universitas Bina Sarana Informatika \\ e-mail: ${ }^{1}$ muhammad.mku@bsi.ac.id \\ ${ }^{2}$ Fakultas Teknologi Komputer, Universitas Bina Sarana Informatika \\ e-mail: ${ }^{2}$ ifan.mii@bsi.ac.id \\ ${ }^{3}$ Fakultas Teknologi Komputer, Universitas Bina Sarana Informatika \\ e-mail: ${ }^{3}$ arief.afe@bsi.ac.id \\ ${ }^{4}$ Universitas Bina Sarana Informatika \\ e-mail: ${ }^{4}$ rizka.rzl@bsi.ac.id

$\begin{array}{ccc}\text { Diterima } & \text { Direvisi } & \text { Disetujui } \\ 12-12-2019 & 15-12-2019 & 17-12-2019\end{array}$

\begin{abstract}
Abstrak - Perkembangan teknologi informasi sangat berperan di dunia pendidikan, bahkan bisa menjadi tolak ukur dalam menentukan kualitas suatu pendidikan, mulai dari proses kegiatan pembelajaran hingga pengelolaan informasi manajemen sekolah untuk mendukung proses pendidikan. Di Sekolah Menengah Kejuruan Nahdlatul Ulama, proses pencatatan pembayaran biaya Sumbangan Partisipasi Pendidikan (SPP) masih dilakukan manual, tentu saja hal ini tidak efisien karena akan membutuhkan waktu yang lama apabila ada banyak siswa yaang akan membayarnya. Dalam proses pembuatan laporan, petugas harus merekap ulang setiap bulannya dan diberikan kepada kepala sekolah. Terlebih masih saja ada siswa yang tidak jujur dengan tidak membayarkan uang yang telah diberikan orangtuanya untuk membayar SPP. Tujuan dari penulisan ini yaitu merancang sebuah sistem informasi pembayaran SPP terintegrasi SMS Gateway, dengan tujuan memecahkan masalah tersebut. Metode yang digunakan adalah metode waterfall sebagai metode pengembangan perangkat lunaknya. Hasil dari penelitian yag dilakukan yakni, menciptakan sistem informasi pembayaran SPP yang sudah terkomputerisasi dan terintegrasi SMS Gateway, dimana nantinya pencatatan laporan bisa dilakukan secara cepat, tidak akan ada lagi siswa yang tidak membayarkan biaya SPPnya, laporan SMS akan terkirim langsung kepada oranguta siswa setiap melakukan pembayaran SPP.
\end{abstract}

Kata Kunci: SMS Gateway, Pembayaran SPP, Waterfall

\section{PENDAHULUAN}

Sekolah merupakan salah satu lembaga yang memberikan pendidikan pelayanan formal kepada masyarakat. Sekolah berfungsi sebagai tempat untuk mengembangkan sarana didik dalam menumbuhkan sikap jujur, bertanggung jawab dan pengetahuan, juga dalam pengembangan bakat maupun skill yang akan menjadi karakter baik dari seseorang (Eko, 2016).

Perkembangan teknologi informasi saat ini, mendorong perubahan dari berbagai bidang kehidupan. Salah satunya adalah kebutuhan informasi yang harus berkualitas yaitu informasi yang relevan, cepat, akurat dan tepat waktu sehingga dapat menjadi dasar pengambilan keputusan (Bayu, 2017).

Perkembangan teknologi informasi juga sangat berperan di dunia pendidikan. Teknologi informasi sudah sering digunakan untuk meningkatkan kualitas suatu pendidikan, mulai dari proses kegiatan pembelajaran hingga pengelolaan informasi manajemen sekolah untuk mendukung proses pendidikan. Untuk itu, setiap lembaga yang bergerak di bidang pendidikan harus menerapkan teknologi informasi dalam berbagai hal yang akan mendukung proses pendidikan sehingga terwujud pendidikan yang berkualitas (Setiawan, 2018).

Sebagaimana permasalahan yang ada di Sekolah Menengah Kejuruan (SMK) Nahdlatul Ulama Tasikmalaya, dalam proses pencatatan pembayaran biaya Sumbangan Partisipasi Pendidikan (SPP) masih diakukan manual, belum terkomputerasi. Tentu saja hal ini tidak efisien karena akan membutuhkan waktu yang lama apabila ada banyak siswa yang akan membayar biaya SPP. Kemudian masalah lain yang timbul adalah pembuatan laporan, petugas harus merekap ulang 
setiap bulannya dan kemudian diberikan langsung kepada Kepala Sekolah. (Anwar, 2016)

Selain masalah diatas, keterlambatan pembayaran siswa juga sering terjadi. Jika siswa terlambat maka siswa tersebut akan diberitahu oleh wali kelas. (Setiawan, 2017). Namun, tidak sedikit siswa yang menyampaikan pemberitahuan secara lisan ini kepada orangtua mereka. Oleh karena itu, dibutuhkan media komunikasi yang tepat antara pihak sekolah dan orangtua mengenai laporan itu. Disamping itu, masih banyak juga siswa yang tidak jujur dalam proses pembayaran biaya SPP. Uang bayaran telah diberikan oleh orangtua kepada putra/putrinya namun namun tidak dibayarkan kepada sekolah, bahkan dibelanjakan untuk keperluan pribadinya. Tentu hal ini tidak sejalan dengan pemanfaatan teknologi informasi dan harus segera diatasi.

\section{METODE PENELITIAN}

Metode penelitian yang digunakan yakni metode pengembangan perangkat lunak dan teknik pengumpulan data :

\section{A. Metode Pengembangan Perangkat Lunak}

Metode yang digunakan dalam pegembangan perangkat lunak ini menggunakan metode waterfall menurut (Pressman, 2015), terdapat lima tahapan dalam megembangkan perangkat lunak, yaitu :

1. Communicartion, komunikasi dalam hal ini terutama terkonsentrasi pada dua hal, analisis bisnis dan perumusan. Analisis bisnis akan mendefinisikan hal-hal apa saja yang akan termuat di dalam aplikasi web. Misalnya pengguna web yang akan dibangun, perubahan potensial dalam lingkungan bisnis, integrasi antara web yang akan dibangun dengan situasi bisnis perusahaan, maupun database perusahaan.

2. Planning, perenanaan proyek pengembangan aplikasi web kemudian ditentukan, perencanaan terdiri dari pendefinisian pekerjaan dan target waktu atas pekerjaan maupun sub pekerjaan yang ditentukan tersebut.

3. Modelling, tujuan dari aktivitas ini adalah untuk menjelaskan hal-hal apa saja yang memang diperlukan atau dibutuhkan pada apllikasi yang akan dibangung dan solusi yang ditawarkan yang dihrapkan dapat menjawab apa yang tersirat dari hasil-hasil analisis dan pengumpulan data.

4. Construction, pembangunan aplikasi web memadukan antara perkembangan teknologi dengan tools pengembangan web yang telah ada, artinya memilih tools yang efektif namun tetap dapat menyesuaikan dengan teknologi yang berkembang saat ini.

5. Deployment, aplikasi web diciptakan untuk dapat berguna bagi kebutuhan pekerjaan, dapat diperasikan oleh end-user, dan kemudian dilakukan evaluasi secara berkala, memberi masukan-masukan kepada team pengembang dan apabila diperlukan akan dilakukan modifikasi pada aplikasi web tersebut.

\section{B. Teknik Pengumpulan Data}

Sedangkan menurut (Raharjo, 2015) untuk pengumpulan data dilakukan dengan tiga metode, diantaranya :

1. Wawancara

Pengumpulan data dilakukan dengan cara mengadakan tanya jawab dengan pegawau tata usaha di SMK NU Kota Tasikmalaya, guna mendapatkan data yang sesuai dengan kebutuhan.

2. Observasi

Pengumpulan data juga dilakukan dengan melakukan pengamatan langsung pada aplikasi SPP yang sudah ada sebelumnya.

3. Studi Pustaka

Studi pustaka dilakukan dengan mencari informasi-informasi yang menunjang dari jurnal maupun buku yang bersangkutan dengan penelitian.

\section{HASIL DAN PEMBAHASAN}

\section{A. Rancangan Basis Data}

Dalam rancangan basis data ini, penulis menjelaskan mengenai Entity Relationship Diagram (ERD) dan Logical Relationship Structure (LRS).

\section{Entity Relationship Diagram (ERD)}

Entity Relationship Diagram (ERD) merupakan diagram yang menggambarkan persepsi dari pemakai dan berisi objek - objek dasar yang disebut entitas da hubungan antar entitas tersebut yang disebut relationship. (Fathansyah, 2015).

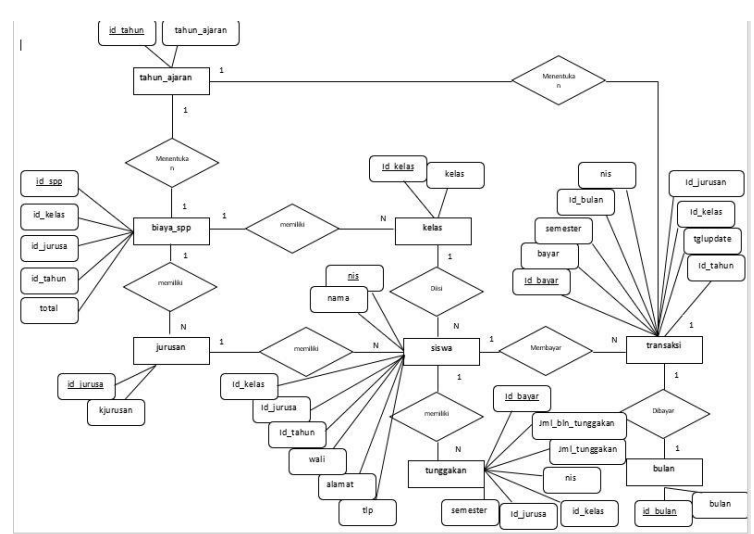

Sumber : (Rifqi Firdaus, Ifan Rifani, Sena, \& Dahlia,2018)

Gambar 1. Rancangan ERD 


\section{Logical Relationship Structure (LRS)}

Logical Record Structure (LRS) dibentuk dengan nomor tipe record. Beberapa tipe record digambarkan oleh kotak empat perseg

i panjang dan dengan nama yang unik. (Lestari, 2015)

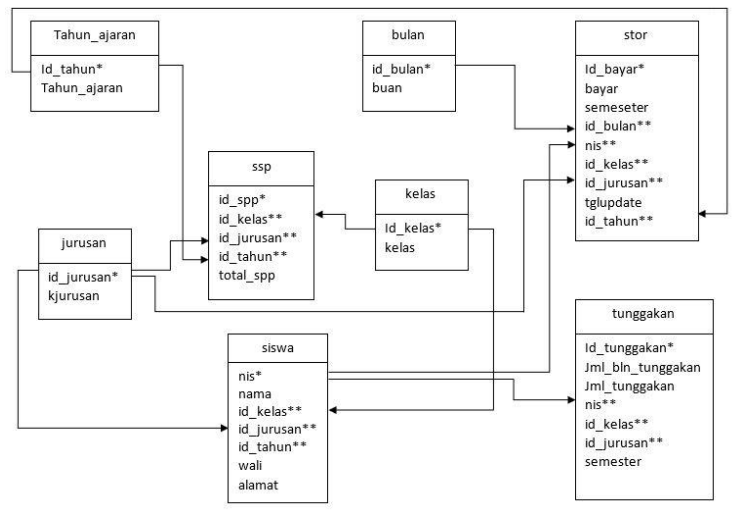

Sumber : (Rifqi Firdaus et al., 2018)

Gambar 2. Rancangan LRS

\section{B. Rancangan Struktur Navigasi}

Struktur navigasi merupakan struktur atau alur dari suatu program yang merupakan rancangan hubungan (rantai kerja) dari beberapa area yang berbeda dan dapat membantu mengorganisasikan seluruh elemen pembuatan website. (Andre, 2014).

Rancangan struktur navigasi dari aplikasi yang dibuat diantaranya yaitu struktur navigasi untuk admin dan pengguna.

1. Struktur Navigasi Admin

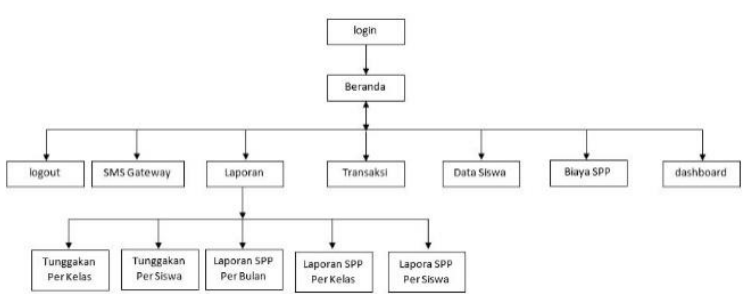

Sumber : (Rifqi Firdaus et al., 2018)

Gambar 3. Struktur Navigasi Admin

2. Struktur Navigasu Pengguna

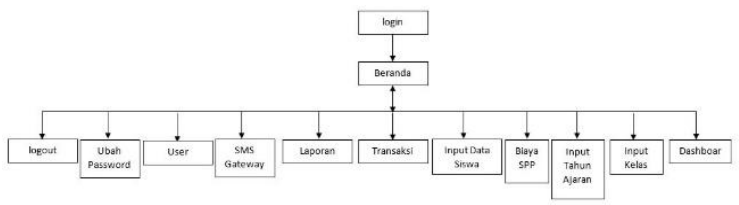

Sumber : (Rifqi Firdaus et al., 2018)

Gambar 4. Struktur Navigasi Penguna

\section{Implementasi Rancangan Antarmuka}

1. Halaman Login

Pada halaman ini terdapat form login untuk mengakses aplikasi pembayaran Sumbanga Partisipasi Pendidikan. Lihat pada gambar dibawah ini :

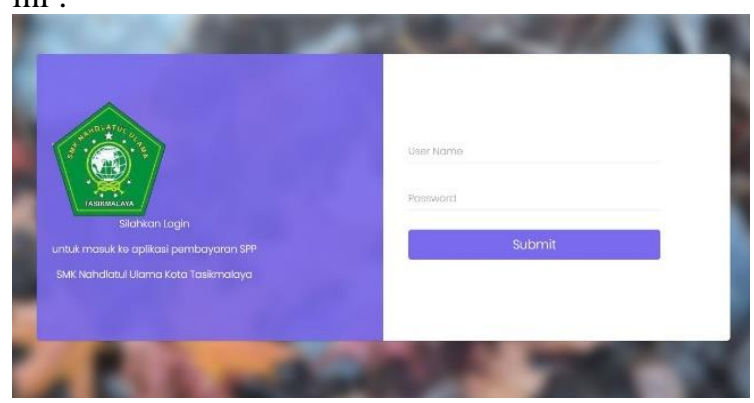

Sumber : (Rifqi Firdaus et al., 2018)

Gambar 5. Implementasi Halaman Login

2. Halaman Utama Admin

Halaman ini merupakan halaman admin untuk mengelola keseluruhan data pembayaran Sumbangan Partisipasi Pendidikan, dan ada juga tombol untuk menghidupkan dan mematikan services Gammu. Lihat gambar dibawah ini:

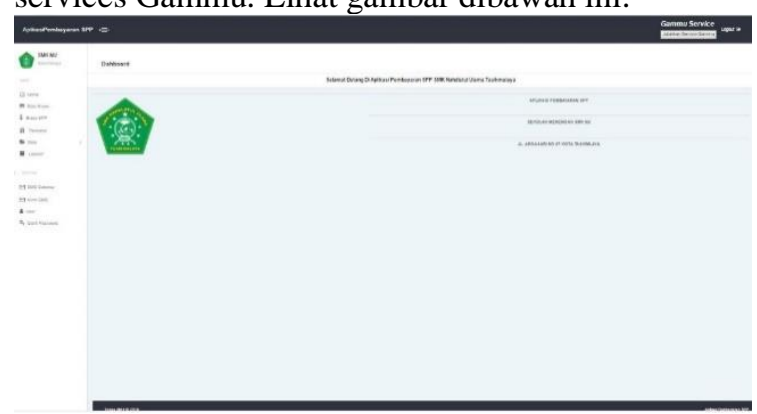

Sumber : (Rifqi Firdaus et al., 2018)

Gambar 6. Implementasi Utama Admin

3. Halaman Data Siswa

Pada halaman ini akan memunculkan data siswa, admin dapat menambah, mengedit dan menghapus data siswa ini. Lihat gambar dibawah ini:

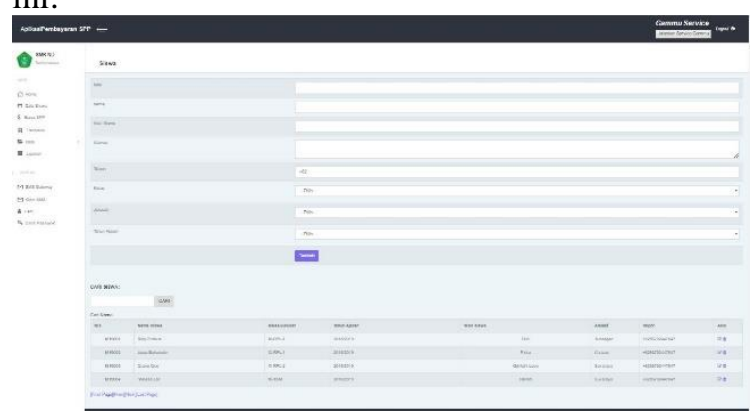

Sumber : (Rifqi Firdaus et al., 2018)

Gambar 7. Implementasi Halaman Data Siswa

4. Halaman Data Biaya Sumbangan Partisipasi Pendidikan

Pada halaman ini aka memunculkan data biaya Sumbangan Partisipasi Pendidikan (SPP), admin dapat mengatur biaya SPP untuk setiap tahun 
ajarannya. Admin juga bisa menambah, mengedit dan menghapus data biaya SPP ini. Lihat gambat dibawah ini :

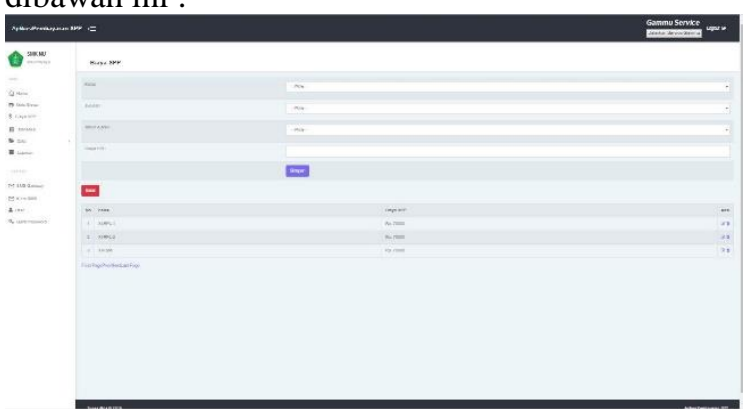

Sumber : (Rifqi Firdaus et al., 2018)

Gambar 8. Implementasi Halaman Data Biaya Sumbangan Partisipasi Pendidikan

\section{Halaman Data Transaksi}

Pada halaman ini, admin akan mengelola transaksi semua siswa yang masuk, admin juga dapat menambah, menghapus juga mencetak laporan pembayaran biaya Sumbangan Partisipasi Pendidikan. Lihat gambar dibawah ini :

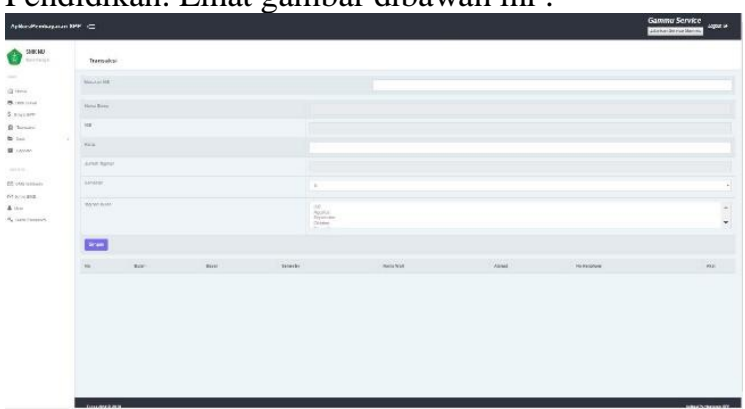

Sumber : (Rifqi Firdaus et al., 2018)

Gambar 9. Implementasi Halaman Data

\section{Transaksi}

\section{Halaman Data Kelas}

Pada halaman ini, menampilkan data kelas. Admin bisa menambah, mengedit dan menghapus data kelas. Lihat gambar dibawah ini :

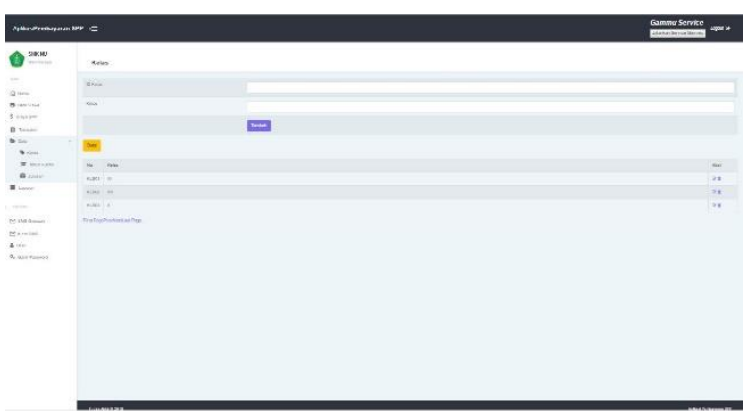

Sumber : (Rifqi Firdaus et al., 2018)

Gambar 10. Implementasi Halaman Data Kelas

\section{Halaman Tahun Ajaran}

Pada halaman ini, menampilkan data tahun ajaran. Admin bisa menambah, mengedit dan menghapus data tahun ajaran. Untuk melihar data tahun ajaran lihat gambar dibawah ini :

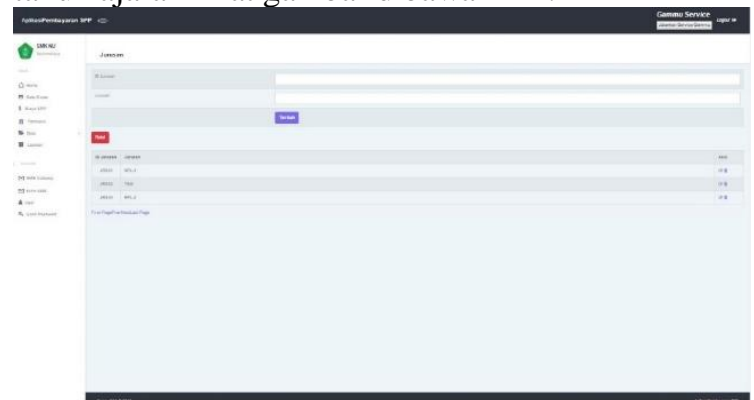

Sumber : (Rifqi Firdaus et al., 2018)

Gambar 11. Implementasi Halaman Tahun Ajaran

\section{Halaman Data Jurusan}

Pada halaman ini, menampilkan data jurusan, admin bisa menambah, mengedit dan menghapus data jurusan. Tampilan data jurusan bisa dilhat pada gambar dibawah ini :

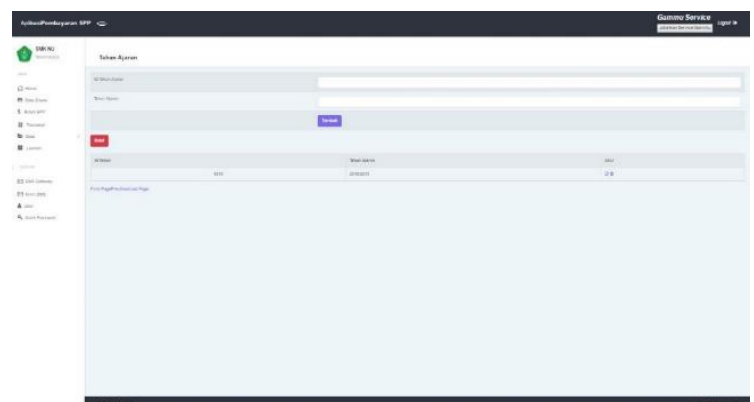

Sumber : (Rifqi Firdaus et al., 2018)

Gambar 12. Implementasi Halaman Data Jurusan

\section{Halaman SMS Gateway}

Pada halaman ini, merupakan server dari SMS Gateway untuk mengirimkan pesan balasan secara otomatis. Lihat gambar dibawah ini:

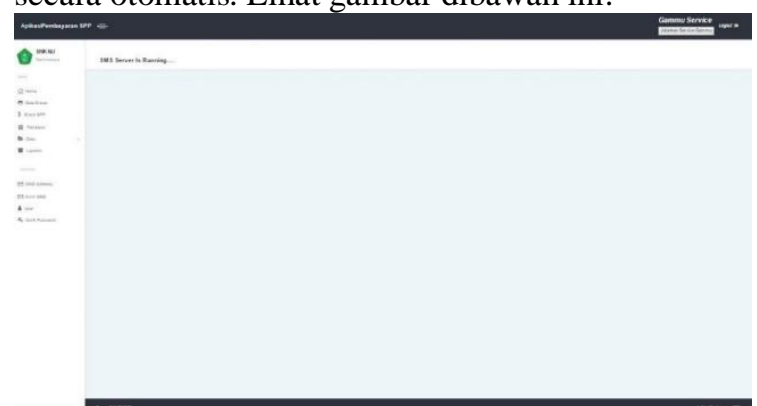

Sumber : (Rifqi Firdaus et al., 2018)

Gambar 13. Implementasi Halaman SMS Gateway

\section{Halaman Kirim SMS}

Pada halaman ini, menampilkan data - data siswa yang masih menunggak pembayarannya. Petugas akan mengirimkan SMS berupa laporan 
tunggakan yang harus segera dibayarkan. Lihat pada gambar dibawah ini :

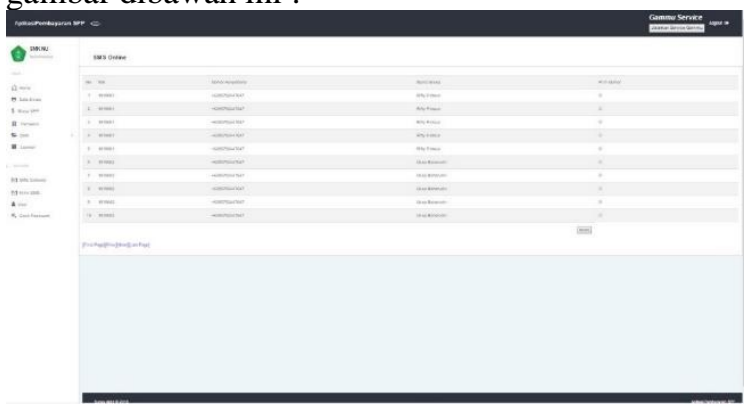

Sumber : (Rifqi Firdaus et al., 2018)

Gambar 14. Implementasi Halaman Kirim SMS

\section{Halaman Data Pengguna}

Pada halaman ini, menampilkan data user yang memiliki hak akses pada aplikasi ini. Admin bisa menambah, mengedit dan menghapus data pengguna. Lihat gambar dibawah ini :

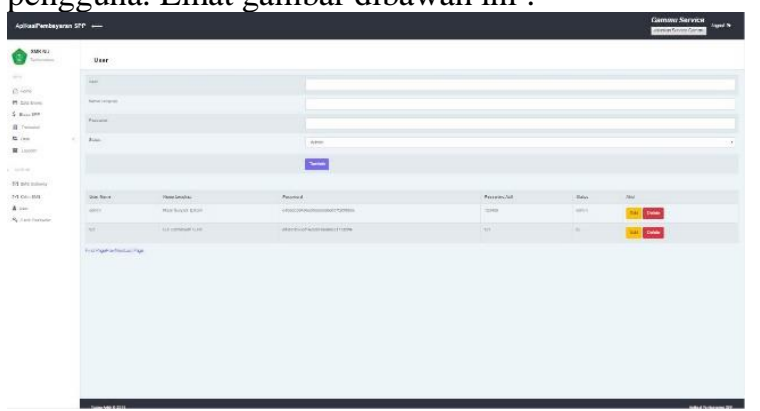

Sumber : (Rifqi Firdaus et al., 2018)

Gambar 15. Implementasi Halaman Data Pengguna

\section{Halaman Ubah Password}

Pada halaman ini, admin dan petugas bisa mengubah password dari masing - masing akun.. Lihat gambar dibawah ini :

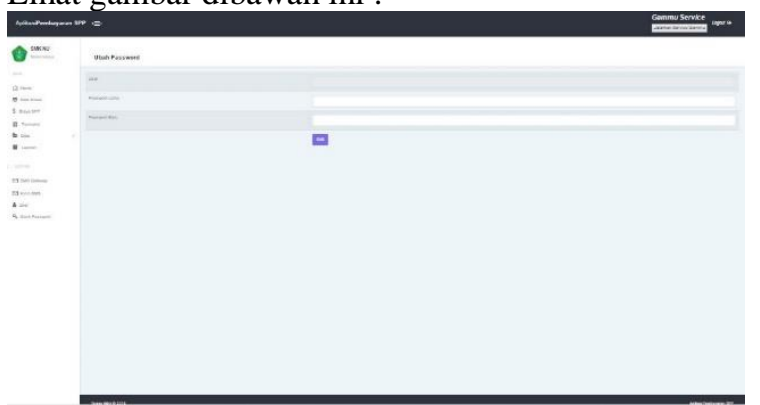

Sumber : (Rifqi Firdaus et al., 2018)

Gambar 16. Implementasi Halaman Ubah Password

\section{Halaman Laporan Pembayaran}

Pada halaman ini, menampilkan laporan pembayaran dari siswa yang telah melakukan transaksi. Lihat pada gambar dibawah ini :

\section{LAPORAN PEMBAYARAN}

$\begin{array}{ll}\text { NIM } & : 1819001 \\ \text { NAMA } & : \text { Rifqi Firdaus } \\ \text { Kelas } & : \text { XI } \\ \text { Jurusan } & : \text { RPL-1 } \\ \text { SMESTER } & : 1 \\ \text { TAHUN AJARAN } & : 2018 / 2019\end{array}$

\begin{tabular}{c|l|c|c|}
\hline NO. & \multicolumn{1}{|c|}{ BULAN } & TANGGAL BAYAR & JUMLAH \\
\hline 1 & JULI & $05 / 08 / 2018$ & Rp. $75.000,00$ \\
\hline 2 & AGUSTUS & $05 / 08 / 2018$ & Rp. $75.000,00$ \\
\hline 3 & SEPTEMBER & $05 / 08 / 2018$ & Rp. $75.000,00$ \\
\hline 4 & OKTOBER & $05 / 08 / 2018$ & Rp. $75.000,00$ \\
\hline 5 & NOVEMBER & $05 / 08 / 2018$ & Rp. $75.000,00$ \\
\hline 6 & DESEMBER & $05 / 08 / 2018$ & Rp. $75.000,00$ \\
\hline & \multicolumn{2}{|c|}{ Jumlah Total } & Rp. $\mathbf{4 5 0 . 0 0 0 , 0 0}$ \\
\hline
\end{tabular}

Sumber : (Rifqi Firdaus et al., 2018)

Gambar 17. Implementasi Halaman Laporan Pembayaran

\section{Halaman Laporan Tunggakan}

Pada halaman ini, menampilkan laporan tunggakan siswa per siswa dan juga perkelas. Lihat gambar dibawah ini :

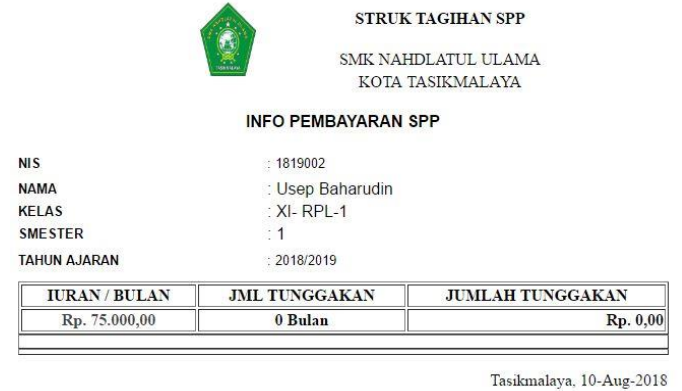

Sumber : (Rifqi Firdaus et al., 2018)

Gambar 18. Implementasi Halaman Laporan Tunggakan

\section{KESIMPULAN}

Berdasarkan pembuatan sistem informasi pemayaran SPP terintegrasi SMS Gateway dan berbagai paparan sebelumnya di atas, dapat disimpulkan bahwa:

Terimplementasinya perancangan sistem informasi pembayaran SPP yang terintegrasi SMS Gateway dengan menggunakan bahasa pemograma PHP dan database MySQL.

Sistem pembayaran SPP yang diterapkan diSMK Nahdatul Ulama (NU) lebih mudah dan efisien dalam melakukan transaksi dan pembuatan laporan.

Dengan SMS Gateway, setiap transaksi yang dilakukan akan langsung mengirimkan laporan melalui SMS kepada orang tua siswa.

Website ini juga bisa mengirim SMS kepada 
orang tua siswa untuk mengingkatkan pembayaran masih menunggak.

\section{REFERENSI}

Andre. (2014). Macam-macam Struktur Navigasi Pada Website. Retrieved from https://www.andre.web.id/struktur-navigasiwebsite/\%0D

Anwar, K. L. (2016). Rancang Bangun Sistem Informasi Tugas Akhir Berbasis SMS Gateway.

Bayu, I. G. N. A. (2017). ANALISIS WACANA KRITIS TENTANG ISU REKLAMASI TELUK BENOA DALAM WEBSITE BALITRIBUNNNEWS.COM.

Elektro, J. T., Jurusan, M., \& Elektro, T. (2016). Rancang Bangun Sistem Informasi Tugas Akhir Berbasis SMS Gateway ( Studi Kasus di Jurusan Teknik Elektro Universitas Bangka Belitung ) JURNAL Untuk Memenuhi Sebagian Persyaratan Mencapai Derajat Sarjana S-1 Khusni Latiful Anwar Rancang Bangun Sistem Infor. Retrieved from http://ebook.ubb.ac.id/assets/file/Sistem_Infor masi_Tugas_Akhir_Berbasis_SMS_Gateway. pdf

Fathansyah. (2015). Basis Data Revisi Kedua.
Bandung: Informatika.

Lestari. (2013). Pengertian Logical Record Structure. Retrieved from https://brainly.co.id/tugas/263826

Pressman, R. (2015). Software Engineering Seventh Edition, 9-38. Retrieved from http://library.binus.ac.id/eColls/eThesisdoc/Ba b2/2014-2-01054-MTIF Bab2001.pdf

Raharjo, B. (2015). Mudah Belajar PHP Teknik Penggunaan Fitur-Fitur Baru Dalam PHP 5. (Informatika, Ed.). Bandung.

Rifqi Firdaus, M., Ifan Rifani, M., Sena, A. rama, \& Dahlia, R. (2018). SISTEM INFORMASI PEMBAYARAN SUMBANGAN PARTISIPASI PENDIDIKAN TERINTEGRASI SMS GATEWAY.

SETIAWAN, D. (2017). Buku Sakti Pemrograman WEB. (S. Adams, Ed.) (1st ed.). Yogyakarta: START UP.

Setiawan, R. (2018). Metodologi Penelitian Teknologi Informasi. (S. Rizky Wicaksono, Ed.). Malang: CV. Seribu Bintang. 